\title{
A review on tobacco and its effect on health
}

\author{
B. Lalruatfela \\ Department of Life Sciences, Pachhunga University College, Aizawl 796001, Mizoram, India
}

\begin{abstract}
Tobacco is an important agricultural product that is consumed all over the world. More than 8000 chemicals are reported to be present in tobacco, and a large number of these chemicals are known carcinogens, and hence is known to be one of the most significant contributors to the development of cancer of different body parts. These chemicals have been reported to alter both the genetic and epigenetic constituents of cells. Such changes involve point mutation, deletion, insertion, recombination, transversion, transition, and chromosomal aberrations including aneuploidy and polyploidy. The chemical composition of different types of tobacco has been reported to be different. In this article, brief information about tobacco plants; history, types and popularity of tobacco; its chemical composition; relation to cancer and other diseases and its effects on the molecular, epigenetic and genetic compositions have been highlighted.
\end{abstract}

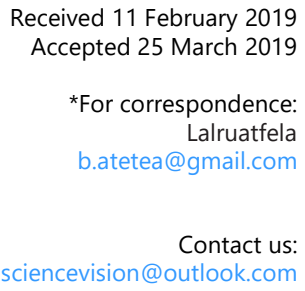

Keywords: Cancer, health, Nicotiana, smokeless, smoking, tobacco.

\section{Introduction}

Tobacco is an important agricultural product processed from the plant of the genus Nicotiana belonging to the family Solanaceae. ${ }^{1}$ There are 72 known species of Nicotiana, however, $N$. tabacum and $N$. rustica are of major economic importance as they are consumed in various forms. ${ }^{2}$ Tobacco plants are known to prosper in tropical and subtropical climatic conditions and are either cultivated or found in the wild. The body of a tobacco plant consists of a hollow, spongy stem and is mostly one to two meters tall depending on the species and variety. The leaves are covered by minute viscid glandular hairs and the plants mostly thrive in moist soil and humid environment. Any part of the plant is processed into other products for consumption. These products are referred to as tobacco while the plant is referred to as a tobacco plant. The method of processing and consumption varies considerably throughout the world. It is consumed singly or in combination with other ingredients. ${ }^{3}$
The first known users of tobacco are the Native Americans, which was reported by Christopher Columbus and his expedition crew around the $15^{\text {th }}$ century. The European explorers, during the great exploration era, introduced it to other parts of the world, initially as a medicine and then as a recreational product. The introduction to other parts of the world was heavily criticized and banned by kings and religious leaders. However, the impact of tobacco on a country's economy and the comprehensive admiration among the general populous obligated these leaders to accept it. ${ }^{4,5}$ The initial use of tobacco by the Native Americans was said to be of medicinal and spiritual purposes. The many chemicals present in tobacco have hallucinogenic properties and this particular property was known to be desired by the Native Americans to make contact with the spiritual world. The medicinal purpose of tobacco consumption is its property to alleviate pain. It was used to cure earache, toothache, asthma, tuberculosis, common cold and some skin diseases of domestic swine. ${ }^{6}$ 
Tobacco consumption is popular all over the world. In fact, every nation throughout the world is a nation with tobacco users in its population. ${ }^{7}$ It is estimated that there are approximately 1 billion men and 250 million women who used tobacco globally. ${ }^{8-}$ ${ }^{10} \mathrm{As}$ a general consequence, an individual's habit of consuming any form of tobacco is an influence of peers or popular culture. Most tobacco users started the practice during adolescent or early adulthood. During the early stage of usage, users claimed to have pleasurable sensations which served as a positive reinforcement. This positive reinforcement gradually compelled the users to be habituated to it. This habituation is an effect of nicotine, a powerful addictive chemical in the tobacco. Once the users are habituated to tobacco, or more specifically nicotine, they found it exceptionally challenging to discontinue its consumption. The discontinuance of tobacco consumption by habituated users leads to withdrawal symptoms, which include anxiety, restlessness, irritability, shortened attention span and intense craving for tobacco or nicotine. ${ }^{11}$

Although nicotine is non-carcinogenic, ${ }^{12-14}$ its effect on the physiological and psychological construct of the body is immense, with elevation of heart rate, blood pressure, cardiac output and oxygen consumption; relaxed the musculo-skeletal dynamics and cognizance; increased alertness and brought euphoria to the users. It also decreases muscular strength and lowers anaerobic performance. Nicotine has also been reported to have damaging effect on DNA of cultured epithelial and non-epithelial human cells. ${ }^{15-17}$

\section{Systematic classification}

$\begin{array}{ll}\text { Kingdom: } & \text { Plantae } \\ \text { Phylum: } & \text { Magnoliophyta } \\ \text { Class: } & \text { Magnoliopsida } \\ \text { Order: } & \text { Solanales } \\ \text { Family: } & \text { Solanaceae } \\ \text { Genus: } & \text { Nicotiana } \\ \text { Species: } & \text { N. tabacum; N. rustica } \\ \text { Binomial: } & \text { Nicotiana tabacum L. } \\ & \text { Nicotiana rustica L. }\end{array}$

\section{Types of Tobacco}

The kind of tobacco and its associated products used worldwide vary considerably from place to place and also depend upon the choice of the individual consumers. The choice of tobacco used often reflects the socio-economic status of the users. Certain tobacco products are rather expensive and their consumptions, in a way, reflect the users' luxurious way of life. The availability of such tobacco products is also an important factor in the users' selection for consumption. Generally, tobacco can be divided into two types, smoking (combustible) and smokeless (non-combustible) tobacco. Smoking is the most common practice of tobacco consumption all over the world and consists of great number of varieties. Every cultures and communities have different specific names or brands for the smoked tobacco products. Some of the most popular varieties include cigarette, cigar, pipe, hookah, bidi, cheroot, cigarillos, little cigar, kreteks, etc. Smoked tobacco products are initially hand rolled, but after the industrial revolution, factories and industries took over its production and is currently one of the biggest industries. ${ }^{18,19}$

Smokeless tobaccos are another form of consumable tobacco product. Many smokeless tobaccos are either sun-dried or fire-dried and are mostly orally consumed, although some are nasally used. There also exist liquid form of tobacco in the north eastern part of India. ${ }^{20,21}$ Some of the popular smokeless tobaccos include chewing tobacco, tuibur or hidakphu (tobacco brew), snuff, khaini, raja, mawa, mishri, snus, betel nut quid, spit tobacco, gutkha, tiranga, shikhar, hogesoppu, kaddipudi, gundi, kiwam, zarda, pattiwala, mainpuri, kharra, bajjar, gul, gudakhu, naswar, etc. The means of consumption of these tobaccos vary greatly; some are ingested while others are simply kept in the mouth and spitted out after some time. ${ }^{22-24}$

\section{Chemical Composition of Tobacco}

Tobacco is known to contain more than 8000 chemicals, out of which more than 80 have probable carcinogenic properties. ${ }^{25-29}$ The soil on which a tobacco plant grows plays a significant role in determining some of the chemicals found in the plant. The plant often absorbs toxic chemicals from the soil along with other nutrients and water and stores it in certain parts of their structure. Therefore, the type and number of chemicals vary among different types of tobacco products. ${ }^{30}$ Some of the common toxic chemicals found in tobacco include benzo[a]pyrene, $\mathrm{N}^{\prime}$-nitrosonornicotine (NNN), N'nitrosoanatabine (NAT), $\mathrm{N}^{\prime}$-nitrosoanabasine (NAB), 4-(methylnitrosamino)-1-(3-pyridyl)-1-butanone (NNK), N-nitrosodimethylamine (NDMA), nitrite, cadmium, lead, arsenic, nickel, chromium, isoprene, styrene, acrylonitrile, acetaldehyde, formaldehyde, polonium-210, benzene, $p$-cresol, $p$-benzoquinone, $\mathrm{N}$-nitrosodiethylamine, ethylenethiourea, chrysene, , mercury, zinc, copper, nicotine, etc. ${ }^{31-34}$

Many of these chemicals exhibit toxic, cytotoxic, genotoxic, mutagenic, teratogenic and carcinogenic properties and some of them are classified under class I carcinogens. The types of chemicals present in smoked and smokeless tobaccos also differ. Many chemicals are synthesized during the burning/ pyrolysis of the tobacco in the process of smoking. ${ }^{35-}$ ${ }^{39}$ In fact, every smoked and smokeless tobacco will have different chemical constituents depending on the method of processing and geographical area of 
the crop production. ${ }^{40,41} \mathrm{~A}$ study on the chemical composition of the tar phase of tuibur, a locally manufactured tobacco brew by the Mizos showed the presence of mainly non-polar organic substances that may be described as semi-volatile and nonvolatile. $^{42}$

\section{TOBACCO AND CANCER}

Although the Native Americans were known to use tobacco as medicine, its detrimental effects on health came to light in the mid- $19^{\text {th }}$ century. From then onwards, the injurious health effect of tobacco has been recorded thousands of times from all over the world. As some of the chemicals of tobacco are carcinogenic, the consumption of tobacco has been associated with many forms of cancer. ${ }^{33,43-47}$ In fact, almost all known cancers can be correlated to tobacco consumption. However, the most direct involvement of cancer can be seen in cancer of the mouth, lungs, esophagus, stomach, liver, pharynx, colon, etc. ${ }^{48-50}$ Some epidemiological studies had shown that smoke and smokeless tobacco increased the risk of gastric cancer. ${ }^{21,51}$ Smoking tobacco alone has also been reported to increase the risk of developing lung cancer. ${ }^{52}$ Individuals having GSTM1 null genotype and GSTT1 non-null genotype with the habit of using tobacco were shown to have a higher risk of developing gastric cancer. ${ }^{53}$

Many studies have shown that individuals smoking a pack of cigarette per day showed 50\% increase in colon cancer than non-smokers and even those who discontinued smoking remained at increased risk for the development of cancer, even if they stopped the habit very early. Contrastingly, some studies have established a protective effect for terminated smoking. The amount an individual smoked may have been a more important factor than the duration of smoking in the development of cancer. The consumption of alcohol in addition to tobacco has also been found to significantly increase the risk of colon cancer. ${ }^{54-56}$ Tobacco smoking, alcohol consumption and betel quid chewing have been observed to significantly increase the risk of lung cancer. ${ }^{57-58}$ Lung, laryngeal and pharyngeal cancers have highest relative risk in current smokers than former smokers. ${ }^{59}$ Smokeless tobacco has also been attributed to increase the risk of many tobacco related cancers. ${ }^{23,60,61}$

\section{IN OTHER DISEASES}

Besides cancer, it has also been known to cause several diseases mostly involving the pulmonary system like bronchitis, asthma, tuberculosis, laryngitis, pharyngitis, etc. and autoimmune rheumatic diseases. ${ }^{62-66}$ Tobacco not only causes cancer deaths but is also responsible for great number ofdeaths from cardiovascular, chronic obstructive pulmonary and degenerative diseases. ${ }^{67-}$ ${ }^{69}$ In 2000, 4.83 million premature deaths worldwide were attributed to tobacco use, of which 2.41 million were in developing and 2.43 million in developed industrialized countries and these numbers are expected to increase up to 10 million a year by $2030 .^{9,70}$ The use of tobacco has also been known to cause adversities in pregnancy outcomes, possibly leading to abortion. ${ }^{71,72}$ Some studies estimated that tobacco use will result in an annual death exceeding approximately 12 million and each year 6.7 million new tobacco related cancer cases diagnosed. ${ }^{8,73}$

\section{MOLECULAR EFFECTS OF TOBACCO}

Tobacco has been known to affect both the genetic and epigenetic components of the cell, thus resulting in abnormal cell proliferation and apoptosis; upregulation of certain oncogenes and inhibition and down regulation of tumour suppressor genes. The genetic effects may be in the form of point mutation, deletion, insertion, recombination, transversion, transition, and chromosomal aberrations including aneuploidy and polyploidy. These gross changes lead to the overexpression or inactivation of certain key cancer related genes. ${ }^{74,75}$ The epigenetic effects include hypermethylation of $\mathrm{CpG}$ islands in the promoter region of tumour suppressor genes, hypomethylation in the promoter region of protooncogenes, acetylation, phosphorylation, ubiquitylation, sumoylation, ribosylation and citrullination of some amino acids of the histone proteins. These changes affect the structure and ultimately the function of DNA, thereby leading to abnormal cellular functions and eventually leading to cancer. $^{76-78}$

The mechanism of action of DNA damage caused by tobacco involved variety of pathways. One pathway involves oxidative stress caused by highly reactive compounds called free radicals. ${ }^{79,80}$ These free radicals were formed within the cell or can come from external source such as tobacco tar. Free radicals present in tobacco tar had been found to penetrate viable cells, bound to DNA and produce nicks in the DNA, thus altering the DNA structure. ${ }^{81-}$ ${ }^{83}$ Tobacco is a rich source of oxidants and thus depletes the antioxidants of the body causing increase oxidative stress. This oxidative stress had been observed to damage sperms. The spermatozoa of smokers had been found to have a significantly higher level of DNA fragmentation, DNA strand break and 8-OHdG DNA adducts than non- 
smokers. ${ }^{9,84-86}$ Other studies had also shown that smoking reduced sperm production and motility. However, some reported smoking to have a negative impact on intracellular antioxidants but did not necessarily increase oxidative DNA damage. ${ }^{87,88}$ In a study involving bladder cancer patients, 4aminobiphenyl-DNA adducts were higher in current smokers than ex-smokers. ${ }^{89,90}$

One of the carcinogens present in tobacco, NNK had been found to alter the structure of XRCC1, a DNA repair protein, therefore decreasing the protein's ability to repair damaged DNA. ${ }^{91}$ One of the most important tumour suppressor genes, p53 had been known to be negatively affected by the use of tobacco in many studies. In head and neck squamous cell carcinoma, p53 and cyclin D1, cell cycle checkpoint genes were found to be mutated and over expressed. ${ }^{92-94}$ In non-small cell lung cancer, exposure to tobacco carcinogens caused mutation in p53, EGFR, hMLH1, FHIT, hMSH3 and D9S157 loci. Majority of these mutations were deletion of a single base pair or more, thus, resulting in loss of heterozygosity. ${ }^{95-98}$ Among lung cancer patients with history of tobacco use and none at all, the pattern of mutation differed. It was found that there was an excess of guanine to thymine transversions in smoking related lung cancers. This $G$ to $\mathrm{T}$ transversion was $30 \%$ prevalent in smokers while it was only $12 \%$ among the non-smokers. ${ }^{99}$ Smokers were also found to have higher number of small chromatid exchanges. ${ }^{100}$

Besides smoking tobacco, the use of smokeless tobacco also demonstrated many genetic alterations between tobacco users and non-users. p53, p21, Kras, Bax, IL-6, TNF- $\alpha$, iNOS and Cox- 2 genes were found to be highly expressed among smokeless tobacco users, whereas $\mathrm{Bcl}-2$ (an important apoptotic gene) expression seemed to decrease. ${ }^{101-}$ 103 However, some studies did not find any correlation between tobacco use and mutations in important genes including $\mathrm{H}$-ras, EGRF, K-ras, p53 and Cox-2. $92-94,104$

\section{References}

1. Knapp, S. (2002). Tobacco to tomatoes: a phylogenetic perspective on fruit diversity in the Solanaceae. Journal of Experimental Botany 53, 20012022.

2. Rudgley, R. (1998). Biopsychiatry. In: Tobacco: From The Encyclopedia of Psychoactive Substances, Little, Brown and Company, pp. 54-86.

3. Kishore, K. (2014). Monograph of tobacco (Nicotiana tabacum). Indian Journal of Drugs 2, 5-23.

4. Goodman, J. (2005). Tobacco in History and Culture: An Encyclopedia. Detroit: Thomson Gale, Granite Hill Publishers, pp. 1-24.
5. West, R. \& Shiffman, S. (2007). Fast Facts: Smoking Cessation. Health Press Ltd., p. 28.

6. Bhardwaj, S. \& Ghakar, S.K. (2004). Ethnomedicinal plants used by the tribal of Mizoram to cure cuts and wounds. Indian Journal of Traditional Knowledge, 4, 75-80.

7. World Health Organization (2015). WHO Global Report on Trends in Prevalence of Tobacco Smoking, 2015. WHO Press, World Health Organization, 20 Avenue Appla, 1211 Geneva 27, Switzerland, pp. 1 -3 .

8. World Health Organization, International Agency for Research on Cancer (2002). IARC Monographs on the Evaluation of Carcinogenic Risks to Humans, 2002 (volume 83), Tobacco Smoke and Involuntary Smoking, p. 1187.

9. Ezzati, M. \& Lopez, A.D. (2003). Estimates of global mortality attributable to smoking in 2000 . Lancet 362, 847-852.

10. Hecht, S.S. (2003). Tobacco carcinogens, their biomarkers and tobacco-induced cancer. Nature Review Cancer 3, 733-744.

11. Benowitz, N.L. (1988). Pharmacological aspects of cigarette smoking and nicotine addiction. New England Journal of Medicine 319, 1318-1330.

12. Biesalski, H.K., Bueno de Mesquita, B., Chesson, A., Chytil, F., Grimble, R., Hermus, R.J., Köhrle, J., Lotan, R., Norpoth, K., Pastorino, U., Thurnham, D. (1998). European Consensus Statement on Lung Cancer: risk factors and prevention. Lung Cancer Panel. CA: A Cancer Journal for Clinicians 48, 167176.

13. Hecht, S.S. (1999). Tobacco smoke carcinogens and lung cancer. Journal of the National Cancer Institute 91, 1194-1210.

14. Hecht, S.S. (2012). Lung carcinogenesis by tobacco smoke. International Journal of Cancer 131, 27242732.

15. Kleinsasser, N.H., Wallner, B.C., Harreus, U.A., Zwickenpfjug, W., Richter, E. (2003). Genotoxic effects of myosmine in human lymphocytes and upper aerodigestive tract epithelial cells. Toxicology 192, 171-177.

16. Chague, F., Guenancia, C., Gudjoncik, A., Moreau, D., Cottin, Y., Zeller, M. (2015). Smokeless tobacco, sports and the heart. Archives of Cardiovascular Disease 108, 75-83.

17. Nielsen, S.S., Franklin, G.M., Longstreth, W.T., Swanson, P.D., Checkoway, H. (2013). Nicotine from edible Solanaceae and risk of Parkinson disease. Annals of Neurology 74, 472-477. 
18. World Health Organization (2006). Tobacco: Deadly in Any Form or Disguise. WHO Press, World Health Organization, 20 Avenue, Appla, 1211 Geneva 27, Switzerland, pp. 6-40.

19. Eriksen, M., Mackay, J., Ross, H. (2012). The Tobacco Atlas (4th edition). Atlanta, Georgia, and World Ling Foundation, New York, American Cancer Society, p. 132.

20. Sinha, D.N., Gupta, P.C., Pednekar, M. (2004). Tobacco water: a special form of tobacco use in the Mizoram and Manipur states of India. National Medical Journal of India 7, 245-247.

21. Lalpawimawha, Lalruatfela, B., Chenkual, S., Ralte, Z., Zomuana, T., Ruatfela, S.T., Lalhruaitluanga, W. (2015). Association of tobacco use, betel consumption and gastric cancer in Mizoram. Science Vision 15, 59-67.

22. Foulds, J., Ramstrom, L., Burke, M., Fagerstrom, K. (2003). Effects of smokeless tobacco (snus) on smoking and public health in Sweden. Tobacco Control 12, 349-359.

23. Gupta, P.C. \& Ray, C.S. (2003). Smokeless tobacco and health in India and South Asia. Respirology 8, 419-431.

24. Lalruatfela, B., Zoremsiami, J., Jagetia, G.C. (2017). In vitro effect of tuibur (tobacco brew) on the viability of human blood lymphocytes. Science Vision 17, 19-24.

25. International Agency for Research on Cancer (2004). IARC Monographs on the Evaluation of Carcinogenic Risks to Humans. Lyon 83, pp. 53-1187.

26. Cooper, R.G. (2006). Effect of tobacco smoking on renal function. Indian Journal of Medical Research 124, 261-268.

27. Ding, Y.S., Zhang, L., Jain, R.B., Jain, J., Wang, R.Y., Ashley, D.L., Watson, C.H. (2008). Levels of tobacco-specific nitrosamines and polycyclic aromatic hydrocarbons in mainstream smoke from different tobacco varieties. Cancer Epidemiology, Biomarkers and Prevention 17, 3366-3371.

28. Perfetti, T.A. \& Rodgman, A. (2011). The complexity of tobacco and tobacco smoke. Beitragezur Tabakforschung International 24, 215-232.

29. Arimilli, S., Damratoski, B.E., Bombick, B., Borgerding, M.F., Prasad, G.L. (2012). Evaluation of cytotoxicity of different tobacco product preparations. Regulatory Toxicolology Pharmacology 64, 350-360.
30. Hoffmann, D., Hoffmann, I., \& EI-Bayoumy, K. (2001). The less harmful cigarette: A controversial issue. A tribute to Ernst L. Wynder. Chemical Research in Toxicology 14, 767-790.

31. Stepanov, I. \& Hecht, S.S. (2005). Tobacco-specific nitrosamines and their pyridine-N-glucuronides in the urine of smokers and smokeless tobacco users. Cancer Epidemiology, Biomarkers and Prevention 14, 885-891.

32. Godwin, W.S., Subha, V.R., Feroz, K.M. (2010). ${ }^{210} \mathrm{Po}$ radiation dose due to cigarette smoking. Current Science 98, 681-686.

33. Talhout, R., Schulz, T., Florek, E., Benthem, J.V., Wester, P., Opperhulzen, A. (2011). Hazardous compounds in tobacco smoke. International Journal of Environmental Research and Public Health 8, 613628.

34. Borgerding, M.F., Bodnar, J.A., Curtin, G.M., Swauger, J.E. (2012). The chemical composition of smokeless tobacco: A survey of products sold in the United States in 2006 and 2007. Regulatory Toxicology Pharmacology 64, 367-387.

35. Chiba, M. \& Masironi, R. (1992). Toxic and trace elements in tobacco and tobacco smoke. Bulletin of WHO 70, 269-275.

36. Stohs, S.J., Bagchi, D., Bagchi, M. (1997). Toxicity of trace elements in tobacco smoke. Inhalation Toxicology 9, 867-890.

37. Demarini, D.M. (2004). Genotoxicity of tobacco smoke and tobacco smoke condensate: A review. Mutation Research 567, 447-474.

38. Eyre, H., Kahn, R., Robertson, R.M., Clark, N.G., Doyle, C., Gansler, T., Glynn, T., Hong, Y., Smith, R.A., Taubert, K., Thun, M.J. (2004). Preventing cancer, cardiovascular disease, and diabetes: a common agenda for the American Cancer Society, the American Diabetes Association, and the American Heart Association. CA: A Cancer Journal for Clinician 54, 190-207.

39. Husgavfel-Pursiainen, K. (2004). Genotoxicity of environmental tobacco smoke: a review. Mutation Research 567, 427-445.

40. Pryor, W.A., Prier, D.G., Church, D.F. (1983). Electron-spin resonance study of mainstream and side stream cigarette smoke: Nature of the free radicals in gas-phase smoke and in cigarette tar. Environmental Health Perspective 47, 345-355.

41. Calafat, A.M., Polzin, G.M., Saylor, J., Richter, P., 
Ashley, D.L., Watson, C.H. (2004). Determination of tar, nicotine, and carbon monoxide yields in the mainstream smoke of selected international cigarettes. Tobacco Control 13, 45-51.

42. Lalmuanpuii, R. \& Muthukumaran, R.B. (2016). Fourier transform-infrared spectroscopic characterization of the particulate phase of commercial tuibur. Science Vision 16, 68-73.

43. Wynder, E.L. \& Wright, G. (1957). A study of tobacco carcinogenesis. I. The primary fractions. Cancer 10, 255-271.

44. Hoffmann, D. \& Wynder, E.L. (1970). A study on tobacco carcinogenesis. XI. Tumor initiators, tumor accelerators and tumor promoting activity of condensate fractions. Cancer 27, 848-864.

45. Bassiony, M.A., Aqil, M., Khalili, M., Radosevich, J.A., Elsabaa, H.M. (2015). Tobacco consumption and oral, pharyngeal and lung cancers. The Open Cancer Journal 8, 1-11.

46. National Cancer Registry Programme (2010). Three year report of the population based cancer registries 2006-2008. (First report of 20 PBCRs in India). Bangalore, Indian Council Medical Research Publication 11, 71-8.

47. Malakar, M., Devi, K.R., Phukan, R.P., Kaur, T., Deka, M., Puia, L., Sailo, L., Lalhmangaihi, T., Barua, D., Rajguru, S.K., Mahanta, J., Narain, K. (2014). p53 codon 72 polymorphism interactions with dietary and tobacco related habits and risk of stomach cancer in Mizoram, India. Asian Pacific Journal of Cancer Prevention 15, 717--723.

48. Jemal, A., Thun, M.J., Ries, L.A., Howe, H.L., Weir, H.K., Center, M.M., Ward, E., Wu, XC., Eheman, C., Anderson, R., Ajani, U.A. (2008), Annual report to the nation on the status of cancer, 1975-2005, featuring trends in lung cancer, tobacco use, and tobacco control. Journal of the National Cancer Institute 100, 1672-1694.

49. Pelucchi, C., Gallus, S., Garavello, W., Bosetti, C., La Vecchia, C. (2008). Alcohol and tobacco use, and cancer risk for upper aerodigestive tract and liver. European Journal of Cancer Prevention 17, 340344.

50. Stewart, B. \& Wild, C.P. (eds.) (2014), International Agency for Research on Cancer, WHO. World Cancer Report 2014, pp. 16-53.

51. Phukan, R.K., Zomawi, E., Hazarika, N.C., Mahanta, J. (2005). Tobacco use and stomach cancer in Mizoram, India. Cancer Epidemiology, Biomarkers and Prevention 14, 1892-1896.

52. Lalpawimawha \& Lalruatfela, B. (2016). Etiology of lung cancer among the Mizo people. Science
Vision 16, 113-122.

53. Malakar, M., Devi, K.R., Phukan, R.P., Kaur, T., Deka, M., Puia, L., Barua, D., Mahanta, J., Narain, K. (2012). Genetic polymorphism of glutathione Stransferase M1 and T1, tobacco habits and risk of stomach cancer in Mizoram, India. Asian Pacific Journal of Cancer Prevention 13, 4725-4732.

54. Wynder, E.L., Mushinski, M.H., Spivak, J.C. (1977). Tobacco and alcohol consumption in relation to the development of multiple primary cancers. Cancer 40, 1872-1878.

55. Mashberg, A., Boffetta, P., Winkelman, R., Garfinkel, L. (1993). Tobacco smoking, alcohol drinking, and cancer of theoral cavity and oropharynx among U. S. veterans. Cancer 72, 16391675.

56. Slattery, M.L., Potter, J.D., Friedman, G.D., Ma, K.N., Edwards, S. (1997). Tobacco use and colon cancer. International Journal of Cancer 70, 259-264.

57. Phukan, R.K., Borah, P.K., Saikia, B.J., Das, M., Sekhon, G.S., Mahanta, J. (2014). Interaction of tobacco smoking and chewing with angiotensin converting enzyme (insertion/deletion) gene polymorphisms and risk of lung cancer in a high risk area from Northeast India. Asian Pacific Journal of Cancer Prevention 15, 10691-10695.

58. Saikia, B.J., Das, M., Sharma, S.K., Sekhon, G.S., Zomawia, E., Singh, Y.M., Mahanta, J., Phukan, R.K. (2014). Association of a p53 codon 72 gene polymorphism with environmental factors and risk of lung cancer: a case control study in Mizoram and Manipur, a high incidence region in North East India. Asian Pacific Journal of Cancer Prevention 15, 10653-10658.

59. Gandini, S., Botteri, E., Iodice, S., Boniol, M., Lowenfels, A.B., Maisonneuve, P., Boyle, P. (2008). Tobacco smoking and cancer: a meta-analysis. International Journal of cancer 122, 155-164.

60. Boffetta, P., Hecht, S., Gray, N., Gupta, P., Straif, K. (2008). Smokeless tobacco and cancer. The Lancet Oncology 9, 667-675.

61. Rose, M.L., Chadha, D., Bhutia, T.D. (2016). Smokeless tobacco use and perceptions of risk among students in Mumbai municipal schools. Indian Journal of Cancer 53, 322.

62. Traber, M.G., Van Der Vliet, A., Reznick, A.Z., Cross, C.E. (2000). Tobacco-related diseases: is there a role for antioxidant micronutrient supplementation? Clinics in Chest Medicine 21, 173187.

63. Musk, A.W.\& De Klerk, N.H. (2003). History of tobacco and health. Respirology 8, 286-290. 
64. Thakur, J.S., Garg, R., Narain, J.P., Menabde, N. (2011). Tobacco use: a major risk factor for noncommunicable diseases in South-East Asia region. Indian Journal of Public Health 55, 155.

65. Elmasry, S., Asfour, S., Vaccari, J.P.R., Travascio, F. (2015). Effects of tobacco smoking on the degeneration of the intervertebral disc: A finite element study. Plos One 1, 1-22.

66. Harel-Meir, M., Sherer, Y., Shoenfeld, Y. (2007). Tobacco smoking and autoimmune rheumatic diseases. Nature Reviews Rheumatology 3, 707.

67. International Agency for Research on Cancer (2007). IARC, Monographs on the evaluation of Carcinogenic Risks to Humans. Smokeless tobacco and some tobacco-specific N-nitrosamines, Lyon, p. 89 .

68. Arnson, Y., Shoenfeld, Y., Amital, H. (2010). Effects of tobacco smoke on immunity, inflammation and autoimmunity. Journal of Autoimmunity 34, J258-265.

69. Warren, C.W., Riley, L., Asma, S., Eriksen, M.P., Green, L., Blanton, C., Loo, C., Batchelor, S., Yach, D. (2000). Tobacco use by youth: a surveillance report from the Global Youth Tobacco Survey project, 78, 868-876.

70. Peto, R., Darby, S., Deo, H., Silcocks, P., Whitley, E., Doll, R. (2000). Smoking, smoking cessation, lung cancer in the UK since 1950: Combination of national statistics with two case-control studies. British Medical Journal 321, 323-329.

71. Kallen, H. (1999). Maternal smoking and congenital heart defects. European Journal of Epidemiology 15, 731-737.

72. Little, J., Cardy, A., Munger, R.G. (2004). Tobacco smoking and oral clefts: a meta-analysis. Bulletin of the World Health Organization 82, 213-218.

73. Lee, Y.C. \& Hashibe, M. (2014). Tobacco, alcohol, and cancer in low and high income countries. Annals of Global Health 80, 378-383.

74. Hainaut, P. \& Pfeifer, G.P. (2001). Patterns of p53 G๑T transversions in lung cancers reflect the primary mutagenic signature of DNA-damage by tobacco smoke. Carcinogenesis 22, 367-374.

75. Valko, M., Izakovic, M., Mazur, M., Rhodes, C.J., Telser, J. (2004). Role of oxygen radicals in DNA damage and cancer incidence. Molecular and Cellular Biochemistry 266, 37-56.

76. Jenuwein, T. \& Allis, C.D. (2001). Translating the histone code. Science 293, 1074-1080.

77. Esteller, M. (2011). Cancer epigenetics for the $21^{\text {st }}$ century: What's next? Genes Cancer 2, 604-606.
78. Breitling, L.P. (2013). Current genetics and epigenetics of smoking/tobacco-related cardiovascular disease. Arteriosclerosis, Thrombosis, and Vascular Biology 33, 1468-1472.

79. Kilinc, M., Okur, E., Kurutas, E.B., Guler, F.I., Yildirim, I. (2004). The effects of Maras powder (smokeless tobacco) on oxidative stress in users. Cell Biochemistry and Function 22, 233-236.

80. Patel, B.P., Rawal, U.M., Rawal, R.M., Shukla, S.N., Patel, P.S. (2008). Tobacco, antioxidant enzymes, oxidative stress, and genetic susceptibility in oral cancer. American Journal of Clinical Oncology 31, 454 -459 .

81. Valavanidis, A., Vlachogianni, T., Fiotakis, K. (2009). Tobacco smoke: involvement of reactive oxygen species and stable free radicals in mechanisms of oxidative damage, carcinogenesis and synergistic effects with other respirable particles. International Journal of Environmental Research and Public Health 6, 445-462.

82. Sun, Y. (1990). Free radicals, antioxidant enzymes, and carcinogenesis. Free Radical Biology and Medicine 8, 583-599.

83. Pryor, W.A. (1997). Cigarette smoke radicals and the role of free radicals in chemical carcinogenicity. Environmental Health Perspective $105,875-882$.

84. Fraga, C.G., Motchnik, P.A., Wyrobek, A.J., Rempel, D.M., Ames, B.N. (1996). Smoking and low antioxidant levels increase oxidative damage to sperm DNA. Mutation Research 351, 199-203.

85. Potts, R.J., Newbury, C.J., Smith, G., Notarianni, L.J., Jefferies, T.M. (1999). Sperm chromatin damage associated with male smoking. Mutation Research 423, 103-111.

86. Sepaniak, S., Forges, T., Gerard, H., Foliguet, B., Bene, M.C., Monnier-Barbarino, P. (2006). The Influence of cigratte smoking on human sperm quality and DNA fragmentation. Toxicology 223, 54 -60 .

87. Mostafa, T. (2010). Cigarette smoking and male infertility. Journal of Advanced Research 1, 179-186.

88. Viloria, T., Meseguer, M., Martinez-Conejero, J.A., O'Conner, J.E., Remohi, J., Pellicer, A., Garrido, N. (2010). Cigarette smoking affects specific sperm oxidative defenses but does not cause oxidative DNA damage in infertile men. Fertility and Sterility 94, 631-637.

89. Martone, T., Airoldi, L., Magagnotti, C., Coda, R., Randone, D., Malaveille, C., Avanzi, G., Merletti, F., Hautefeuille, A., Vineis, P. (1998). 4- 
aminobiphenyl-DNA adducts and p53 mutations in bladder cancer. International Journal of Cancer 75, 512-516.

90. Faraglia, B., Chen, S.Y., Gammon, M.D., Zhang, Y.J., Teitelbaum, S.L., Neugut, A.I., Ahsan, H., Garbowski, G.C., Hibshoosh, H., Lin, D., Kadlubar, F.F., Santella, R.M. (2003). Evaluation of 4-aminobiphenyl-DNA adducts in human breast cancer: the influence of tobacco smoke. Carcinogenesis 24, 719-725.

91. Abdel-Rahman, S.Z. \& El-Zein, R.A. (2000). The 399Gln polymorphism in the DNA repair gene XRCC1 modulates the genotoxic response induced in human lymphocytes by the tobacco-specific nitrosamine NNK. Cancer Letters 159, 63-71.

92. Xu, J., Glimenez-Conti, I.B., Cunningham, J.E., Collet, A.M., Luna, M.A., Lanfranchi, H.E., Spitz, M.R., Conti, C.J. (1998). Alterations of p53, cyclin $\mathrm{D} 1, \mathrm{Rb}$, and H-ras in human oral carcinomas related tobacco use. Cancer 83, 204-212.

93. Vahakangas, K.H., Bennett, W.P., Castren, K., Welsh, J.A., Khan, M.A., Blomeke, B., Alavanja, M.C.R., Harris, C.C. (2001). p53 and K-ras mutations in lung cancers from former and neversmoking women. Cancer Research 61, 4350-4356.

94. Calvez, F.L., Mukeria, A., Hunt, J.D., Kelm, O., Hung, R.J., Taniere, P., Brennan, P., Boffetta, P., Zaridze, D.G., Hainaut, P. (2005). TP53 and KRAS mutation load and types on lung cancers in relation to tobacco smoke: Distinct patterns in never, former, and current smokers. Cancer Research 65, 5076-5083.

95. Hirao, T., Nelson, H.H., Ashok, T.D.S., Wain, J.C., Mark, E.J., Christiani, D.C., Wiencke, J.K., Kelsey, K.T. (2001). Tobacco smoke-induced DNA damage and an early age of smoking initiation induce chromosome loss at 3p21 in lung cancer. Cancer Research 61, 612-615.

96. Zienolddiny, S., Ryberg, D., Arab, M.O., Skaug, V., Haugen, A. (2001). Loss of heterozygosity is related to p53 mutations and smoking in lung cancer. British Journal of Cancer 84, 226-231.

97. Krishnan, V.G., Ebert, P.J., Ting, J.C., Lim, E., Wong, S.S., Teo, A.S.M., Yue, Y.G., Chua, H.H., Ma, X., Loh, G.S.L., Lin, Y., Tan, J.H.J., Yu, K., Zhang, S., Reinhard, C., Tan, D.S.W., Peters, B.A., Lincoln, S.E., Ballinger, D.G., Laramie, J.M.,
Nilsen, G.B., Barber, T.D., Tan, P., Hillmer, A.M \& $\mathrm{Ng}$, P.C. (2014). Whole-genome sequencing of Asian lung cancers: Secondhand smoke unlikely to be responsible for higher incidence of lung cancer among Asian never-smokers. Cancer Research 74, 6071-6081.

98. Pleasance, E.D., Stephens, P.J., O'meara, S., McBride, D.J., Meynert, A., Jones, D., Lin, M.L., Beare, D., Lau, K.W., Greenman, C., Varela, I. (2010). A small-cell lung cancer genome with complex signatures of tobacco exposure. Nature $463,184$.

99. Pfeifer, G.P., Denissenko, M.F., Olivier, M., Tretyakova, N., Hecht, S.S.\& Hainaut, P. (2002). Tobacco smoke carcinogens, DNA damage and p53 mutations in smoking-associated cancers. Oncogene 21, 7436-7451.

100. Van Poppel, G., Verhagen, H., van 't Veer, P., van Bladeren, P.J. (1993). Markers for cytogenetic damage in smokers: Associations with plasma antioxidants and glutathione S-transferase $\mu$. Cancer Epidemiology, Biomarkers and Prevention 2, 441-447.

101. Toyooka, S., Tsuda, T., Gazdar, A.F. (2003). The TP53 gene, tobacco exposure, and lung cancer. Human Mutation 21, 229-239.

102. Biswas, S., Manna, K., Das, U., Khan, A., Pradhan, A., Sengupta, A., Bose, S., Ghosh, S., Dey, S. (2015). Smokeless tobacco consumption impedes metabolic, cellular, apoptotic and systemic stress pattern: A study on government employees in Kolkata, India. Nature Scientific Reports 5:18284.

103. Tam, I.Y.S., Chung, L.P., Suen, W.S., Wang, E., Wong, M.C.M., Ho, K.K., Lam, W.K., Chiu, S.W., Girard, L., Minne, J.D., Gazdar, A.F., Wong, M.P. (2016). Distinct epidermal growth factor receptor and KRAS mutation patterns in non-small cell lung cancer patients with different tobacco exposure and clinicopathologic features. Clinical Cancer Research 12, 1647-1653.

104. Nelson, H.H., Wiencke, J.K., Gunn, L., Wain, J.C., Chriatiani, D.C., Kelsey, K.T. (1998). Chromosome 3p14 alterations in lung cancer: Evidence that FHIT exon deletion is a target of tobacco carcinogens and asbestos. Cancer Research 58, 18041807. 